Monatshefte für Chemie 107, 1153-1165 (1976)

o by Springer-Verlag 1976

\title{
Study of the Mechanism of Hydroformylation at Industrial Reaction Conditions
}

\author{
Mechanism of Hydroformylation, Part III ${ }^{13}$
}

By
Naim H. Alemdaroğlu ${ }^{b}$, Johannes L. M. Penninger ${ }^{c}$, and Ernst Oltay ${ }^{a, d}$

With 6 Figures

(Received December 23, 1974)

With a newly developed analytical technique, i.e. high temperature/pressure IR cell coupled to the reactor, it was possible to study the mechanism of hydroformylation at reaction conditions. It has been conclusively found that the hydrogenolysis of the acyl cobalt complex is performed by $\mathrm{HCo}(\mathrm{CO})_{4}$ and not by molecular $\mathrm{H}_{2}$, as proposed by Heck and Breslow.

Therefore the formation of $\mathrm{HCo}(\mathrm{CO})_{4}$ from $\mathrm{Co}_{2}(\mathrm{CO})_{8}$ is an intermediate step in the sequence of hydroformylation reaction steps. The rate of hydroformylation of any of the olefins is smaller than the rate of formation of $\mathrm{HCo}(\mathrm{CO})_{4}$ from $\mathrm{Co}_{2}(\mathrm{CO})_{8}$. The IR spectra reveal that always more than $30 \%$ of the cobalt is in the form of $\mathrm{HCo}(\mathrm{CO})_{4}$ under the reaction conditions.

It is found that the formation of $\mathrm{HCo}(\mathrm{CO})_{4}$ from $\mathrm{Co}_{2}(\mathrm{CO})_{8}$ is the slowest and most temperature-dependent step of the hydroformylation reaction. Also the reaction between olefin and $\mathrm{HCo}(\mathrm{CO})_{4}$ is slower than the hydrogenolysis of the acyl complex.

The experiments were carried out under industrial oxo conditions. The diffusional effects were eliminated.

\section{Introduction}

36 years after the invention of hydroformylation ${ }^{1}$ its mechanism has not been solved. Among the suggested mechanisms the most widely

a Laboratory for Chemical Technology Twente University of Technology, Enschede, The Netherlands.

b Part of the Ph.D. dissertation 1974. New address: 70 sok. No. 8/7 Bahçelievler, Ankara, Turkey.

c New address: AKZO Chemie Nederland B.V. P.O.B. 247, Amersfoort, The Netherlands.

d New address: Director of the Inst. for Chemical Technology of Organic Materials Johannes Kepler-University. A-4045 Linz/Donau, Austria. 
accepted one, which was developed by Heck and Breslow ${ }^{2,3}$ by modifying the mechanism postulated by Kirch and $\operatorname{Orchin}^{4}$, is as follows ${ }^{5,6,2,3}$ :

$$
\begin{aligned}
& 2 \mathrm{Co} \text { (metal oxide, hydroxide or salt) } \stackrel{8 \mathrm{CO}}{\longrightarrow} \mathrm{Co}_{2}(\mathrm{CO})_{8} \\
& \mathrm{Co}_{2}(\mathrm{CO})_{8}+\mathrm{H}_{2} \rightleftarrows 2 \mathrm{HCo}(\mathrm{CO})_{4} \\
& \mathrm{HCo}(\mathrm{CO})_{4} \rightleftarrows \mathrm{HCo}(\mathrm{CO})_{3}+\mathrm{CO}
\end{aligned}
$$

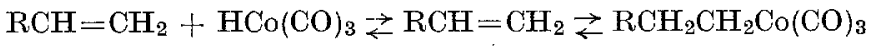

$$
\begin{aligned}
& \mathrm{HCo}(\mathrm{CO})_{3}
\end{aligned}
$$

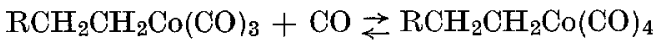

$$
\begin{aligned}
& \mathrm{RCH}_{2} \mathrm{CH}_{2} \mathrm{Co}(\mathrm{CO})_{4} \rightleftarrows \mathrm{RCH}_{2} \mathrm{CH}_{2} \mathrm{COCo}(\mathrm{CO})_{3} \\
& \mathrm{RCH}_{2} \mathrm{CH}_{2} \mathrm{COCo}(\mathrm{CO})_{3}+\mathrm{H}_{2} \rightarrow \mathrm{RCH}_{2} \mathrm{CH}_{2} \mathrm{CHO}+\mathrm{HCo}(\mathrm{CO})_{3} \text {. }
\end{aligned}
$$

The important features of this mechanism are:

1. Before the addition to olefin, elimination of one mole of $\mathrm{CO}$ from hydrocobaltcarbonyl occurs with the formation of an intermediate complex having a co-ordination number which is lowered by one, compared to the hydrocobalttetracarbonyl.

2. Formation of intermediates such as the $\pi$ complex, alkylcobalt complex and acylcobalt complexes occur.

3. The hydrogenation of the acylcobalt complex occurs via molecular hydrogen, giving aldehyde. The recycling catalyst is either $\mathrm{HCo}(\mathrm{CO})_{4}$ or $\mathrm{HCo}(\mathrm{CO})_{3}$.

The hydrogenation of the acylcobalt complex in stoichiometric hydroformylation, i.e. at $1 \mathrm{~atm}$ and $25^{\circ} \mathrm{C}$, and at stoichiometric amounts of $\mathrm{HCo}(\mathrm{CO})_{4}$ and olefin, is suggested to be performed by $\mathrm{HCo}(\mathrm{CO})_{4}$. At catalytic conditions, however, it is believed that this is inoperative.

Most recent literature, published by Gankin et al..$^{-9}$ and Whyman ${ }^{\mathbf{1 0}}$, support Markós findings, that the hydrogenolysis of the acylcobalttetracarbonyl is carried out by $\mathrm{H}_{2}{ }^{11}$.

In order to bring evidences for the above mechanism, we have decided. to study the hydroformylation reaction at catalytic conditions and at high temperature/pressure, with respect to kinetics, catalyst systems and intermediates via the high temperature/pressure IR cell ${ }^{12}$.

\section{Results and Discussion}

The first step of the reaction is the formation of $\mathrm{HCo}(\mathrm{CO})_{4}$ from $\mathrm{Co}_{2}(\mathrm{CO})_{8}$. We have carefully studied this reaction and found all the pertinent data ${ }^{13}$.

Necessary data and thermodynamic parameters, such as activation energies of the forward $(11.7 \mathrm{kcal} / \mathrm{mole})$ and reverse reaction $(17.1 \mathrm{kcal} /$ mole), the enthalpy of reaction $(6.6 \mathrm{kcal} / \mathrm{mole})$, the entropy change 
(14.6 e. u.), heat of formation of $\mathrm{HCo}(\mathrm{CO})_{4}(-146.1 \mathrm{kcal} / \mathrm{mole})$ and the $\mathrm{H}-\mathrm{Co}$ bond strength $(54.7 \mathrm{kcal} / \mathrm{mole})$, have been determined. Also a mechanism has been put forward from the results of the differential pressure measurements, from which the kinetics for the formation of $\mathrm{HCo}(\mathrm{CO})_{4}$ were suggested.

In order to study the mechanism the hydroformylation reaction was performed on the IR assembly ${ }^{13}$ at $125^{\circ} \mathrm{C}, 100 \mathrm{~atm}$ of $\mathrm{CO} / \mathrm{H}_{2}=1$,
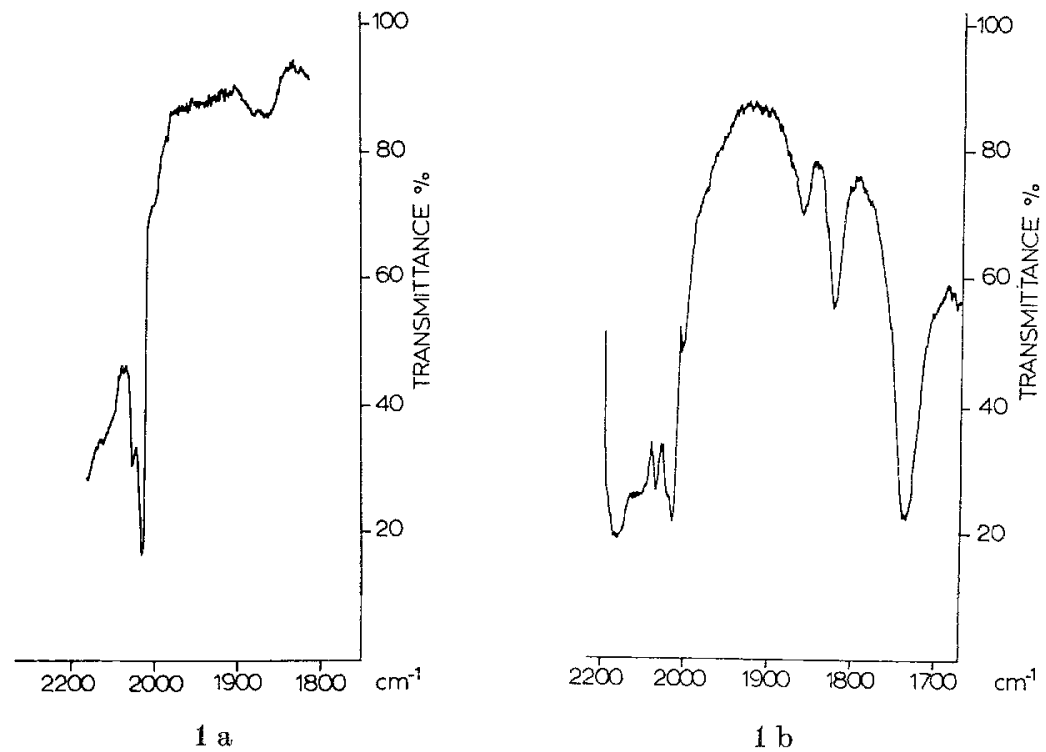

Fig. 1a. IR spectrum of the equilibrium compositions of $\mathrm{Co}_{2}(\mathrm{CO})_{8}$ and $\mathrm{HCo}(\mathrm{CO})_{4}$ at $125^{\circ} \mathrm{C}, 100 \mathrm{~atm}, \mathrm{CO} / \mathrm{H}_{2}=1 / 1$

Fig. $1 \mathrm{~b}$. IR spectrum of the hydroformylation product 1.5 minutes after the injection of pentene at the conditions of Fig. 1 a

with Co/olefin ratio of $5 \times 10^{-3}$, in which pentene was selected as the olefin.

After attaining the equilibrium between $\mathrm{CO}_{2}(\mathrm{CO})_{8}$ and $\mathrm{HCo}(\mathrm{CO})_{4}$ under the conditions mentioned (evident from IR spectra) (Fig. 1 a), pentene was injected into the system.

The IR spectrum (Fig. 1 b), after 1.5 min of reaction time, compared with that at equilibrium conditions, shows a growth in absorbances of $\mathrm{Co}_{2}(\mathrm{CO})_{8}$ at $2068 \mathrm{~cm}^{-1}, 1856 \mathrm{~cm}^{-1}$ (bridging) and a decrease in absorbance of $\mathrm{HCo}(\mathrm{CO})_{4}$ and $\mathrm{Co}_{2}(\mathrm{CO})_{8}$ at $2032 \mathrm{~cm}^{-1}$.

In addition, new absorptions at $1825 \mathrm{~cm}^{-1}$ and. $1730 \mathrm{~cm}^{-1}$, due to olefin and aldehyde respectively, were observed. The shoulder at 
$2010 \mathrm{~cm}^{-1}$ is the only absorption, which is not characterized by added components; it surely belongs to an intermediate. The samples taken during the progress of the reaction were quenched to $-30^{\circ} \mathrm{C}$. The IR spectrum (Fig. 2) of these samples showed characteristic band frequencies of $\mathrm{Co}_{2}(\mathrm{CO})_{8}, \mathrm{HCo}(\mathrm{CO})_{4}$, olefin and aldehyde.

Furthermore, the absorptions at $2108 \mathrm{~cm}^{-1}$ and $2010 \mathrm{~cm}^{-1}$, the

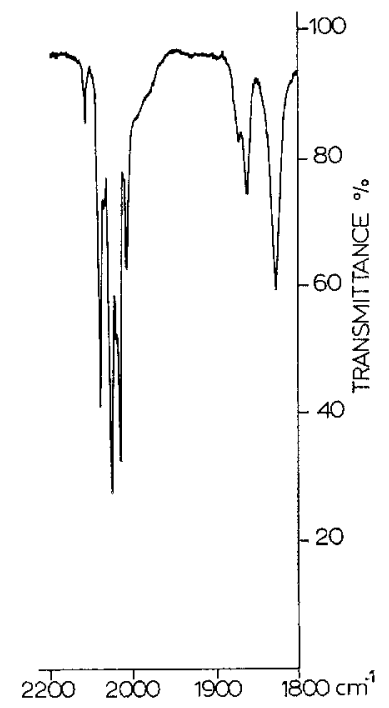

Fig. 2. IR spectrum of the hydroformylation product quenched to $-30^{\circ} \mathrm{C}$. $\mathrm{Co}_{2}(\mathrm{CO})_{8}: 2068 \mathrm{~cm}^{-1}(\mathrm{vs}), 2041 \mathrm{~cm}^{-1}(\mathrm{vs}), 2024 \mathrm{~cm}^{-1}(\mathrm{vs}), 1860 \mathrm{~cm}^{-1}$ (s); $\mathrm{HCo}(\mathrm{CO})_{4}: 2053 \mathrm{~cm}^{-1}$ (vs), $2032 \mathrm{~cm}^{-1}$ (vs); olefin: $1825 \mathrm{~cm}^{-1}$; intermediate: $2107 \mathrm{~cm}^{-1}, 2010 \mathrm{~cm}^{-1}$

intensities of which decreased with time, were observed. These vibrations were assigned to acylcobalttetracarbonyls by Markó et al. ${ }^{11}$.

The IR spectrum of $\mathrm{CH}_{3} \mathrm{Co}(\mathrm{CO})_{4}$ has been reported by them ${ }^{11}$ and the absorptions at $2104.5 \mathrm{~cm}^{-1}, 2035 \mathrm{~cm}^{-1}$ and $2018.5 \mathrm{~cm}^{-1}$ in hexane have been ascribed to it. Since in this region the dissolved $\mathrm{CO}, \mathrm{Co}_{2}(\mathrm{CO})_{8}$ and $\mathrm{HCo}(\mathrm{CO})_{4}$ show strong absorptions, it is impossible to detect the alkyl intermediate even at $-30^{\circ} \mathrm{C}$.

In order to study the mechanism of the reaction, spectra were taken at different reaction times. From these the coneentrations of $\mathrm{Co}_{2}(\mathrm{CO})_{8}$ and $\mathrm{HCo}(\mathrm{CO})_{4}$ were calculated with an accuracy of $4 \%$, from their characteristic absorption bands, with their reported absorptivities ${ }^{13}$. These concentrations were plotted as a function of time (Fig. 3).

Also from the cobalt balance, the difference $(\Delta)$ between the initial $\mathrm{Co}_{2}(\mathrm{CO})_{8}$ charged and the total cobalt, observed as $\mathrm{Co}_{2}(\mathrm{CO})_{8}$ and 
$\mathrm{HCo}(\mathrm{CO})_{4}$, was plotted as a function of time. This difference $\Delta$ is the cobalt that is involved in the reaction or is the amount of intermediates which are bound to cobalt at that particular instant of the reaction.

The results cannot be explained with existing literature. First of all literature claims $\mathrm{HCo}(\mathrm{CO})_{4}$ as the recycling catalyst; therefore one would expect a different pattern of concentration change for $\mathrm{Co}_{2}(\mathrm{CO})_{8}$

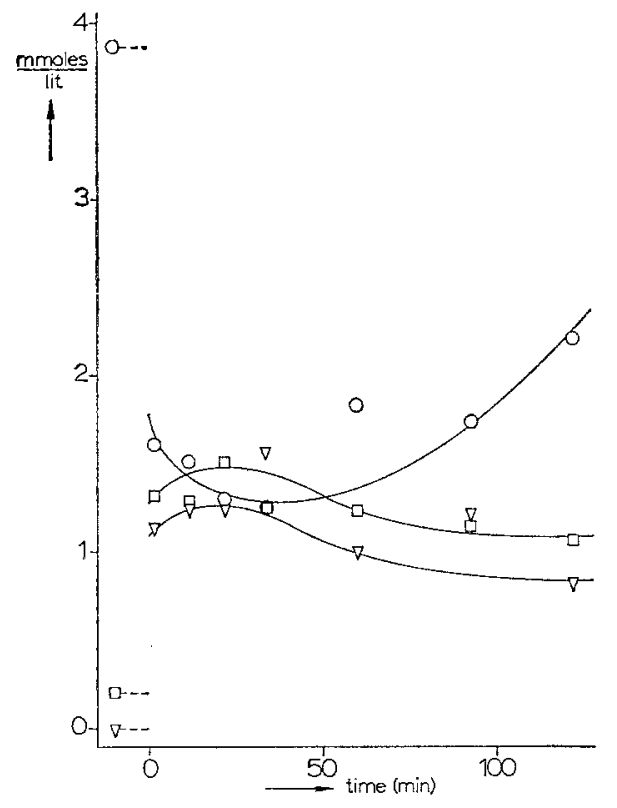

Fig. 3. Change of the concentration of the catalytic species during the hydroformylation of pentene at the conditions of Fig. 1 a. $\square \mathrm{Co}_{2}(\mathrm{CO})_{8}$, $\circ \mathrm{HCo}(\mathrm{CO})_{4}, \nabla \Delta$ (Intermediate)

and $\mathrm{HCo}(\mathrm{CO})_{4}$ from the one observed in Fig. 3. According to the most widely accepted mechanism by Heck and Breslow ${ }^{2}$, the reaction of $\mathrm{HCo}(\mathrm{CO})_{4}$ with olefin should show a decrease in the concentration of the $\mathrm{HCo}(\mathrm{CO})_{4}$ observed. This decrease in $\mathrm{HCo}(\mathrm{CO})_{4}$ would displace the equilibrium of the reaction

$$
\mathrm{Co}_{2}(\mathrm{CO})_{8}+\mathrm{H}_{2} \rightleftharpoons 2 \mathrm{HCO}(\mathrm{CO})_{4}
$$

to the right-hand side, producing more $\mathrm{HCo}(\mathrm{CO})_{4}$, and decrease the concentration of $\mathrm{Co}_{2}(\mathrm{CO})_{8}$.

The decrease of $\mathrm{HCo}(\mathrm{CO})_{4}$ in our observations indicates that $\mathrm{HCo}(\mathrm{CO})_{4}$ is reacting with the olefin. But the increase in $\mathrm{Co}_{2}(\mathrm{CO})_{8}$ is surprising. This increase can in no way be explained with the mecha- 
nism given. It suggests that the hydrogenation reaction of acylcobaltcarbonyl, which is carried out with $\mathrm{H}_{2}$, should be done with $\mathrm{HCo}(\mathrm{CO})_{4}$. Therefore the last step of the mechanism becomes as follows:

$$
\mathrm{R}-\mathrm{CO}-\mathrm{Co}(\mathrm{CO})_{3,4}+\mathrm{HCo}(\mathrm{CO})_{4} \rightarrow \underset{\mathrm{H}}{\mathrm{RC}}=\mathrm{O}+\mathrm{Co}_{2}(\mathrm{CO})_{7,8} .
$$

The mechanism involves $\mathrm{Co}_{2}(\mathrm{CO})_{8}$ as the recycling catalyst instead of $\left.\mathrm{HCo}_{(\mathrm{CO}}\right)_{4}$.

Literature data contradicted this idea for several reasons. One of these is that the greater part of $\mathrm{HCo}(\mathrm{CO})_{4}$ is trapped by the olefin, which is in excess quantity. The break-up could not be carried out with the very low concentration of $\mathrm{HCo}(\mathrm{CO})_{4}$. The observation of Markó et al. ${ }^{11}$ from the samples taken during the hydroformylation of heptene at catalytic conditions, showed no $\mathrm{HCo}(\mathrm{CO})_{4}$ which supported the above reasoning. They also mentioned that towards the end of the reaction, the $\mathrm{HCo}(\mathrm{CO})_{4}$ concentration increased, which might act as a hydrogenation agent.

The graph presented in Fig. 3 shows that the sharp decrease of $\mathrm{HCo}(\mathrm{CO})_{4}$ is being accompanied by a sharp increase in $\mathrm{Co}_{2}(\mathrm{CO})_{8}$ and the cobalt complexed on the intermediates. The steady-state level of the intermediate is $1.27 \mathrm{mmole} / \mathrm{lit}$, which was reached in 13 minutes' time. After $1.5 \mathrm{~min}$ of reaction time $90 \%$ of this level has already been achieved. The cobalt distribution, at the most extreme condition, is such that $37 \%$ of the total cobalt is in the form of $\mathrm{Co}_{2}(\mathrm{CO})_{8} ; 31 \%$ is complexed as the intermediates. The remaining $32 \%$ is in the form of $\mathrm{HCo}(\mathrm{CO})_{4}$, which can perform the hydrogenation of the acylcobaltcarbonyl*. As reaction progresses the olefin is converted into aldehyde and the system attempts to restore the original equilibrium condition by decreasing the quantity of intermediates and $\mathrm{Co}_{2}(\mathrm{CO})_{8}$ and increasing the quantity of $\mathrm{HCo}(\mathrm{CO})_{4}$. It must be kept in mind that the consecutive

* In recent literature Whyman ${ }^{10}$ stated that hydrogenolysis of the acyl complex was the rate determining step owing to the absence of $\mathrm{HCo}(\mathrm{CO})_{4}$ IR adsorption bands during the reaction. This observation is caused by the limitation of his apparatus ${ }^{24}$. In his system he could not observe the shift of the equilibria by the injection of olefin, because all the components of the reaction are charged to the reactor at ambient conditions. The reaction starts as soon as $\mathrm{HCo}(\mathrm{CO})_{4}$ forms during the heat-up period. $\mathrm{HCo}(\mathrm{CO})_{4}$ binds to the olefin, which is in excess quantity, forms and accumulates the acyl complex until its steady-state concentration is reached.

The CO absorption at $2200 \mathrm{~cm}^{-1}$ is smaller at $250 \mathrm{~atm}$ and $150{ }^{\circ} \mathrm{C}$ than at $200 \mathrm{~atm}$ and $150^{\circ} \mathrm{C}$, this indicates that the diffusional limitations in Whyma'ns system were extremely high. This is also another factor which limits the formation of $\mathrm{HCo}(\mathrm{CO})_{4}$ in the reaction, due to the very low concentration of $\mathrm{H}_{2}$ in the liquid phase. 
reaction of alcohol formation consumes $\mathrm{HCo}(\mathrm{CO})_{4}$. Therefore the original equilibrium cannot be achieved.

One of the other oppositions to the break-up mechanism is that the rate of hydroformylation has proved to be faster than the rate of formation of $\mathrm{HCo}(\mathrm{CO})_{4}$, which in this case will be an intermediate reac-

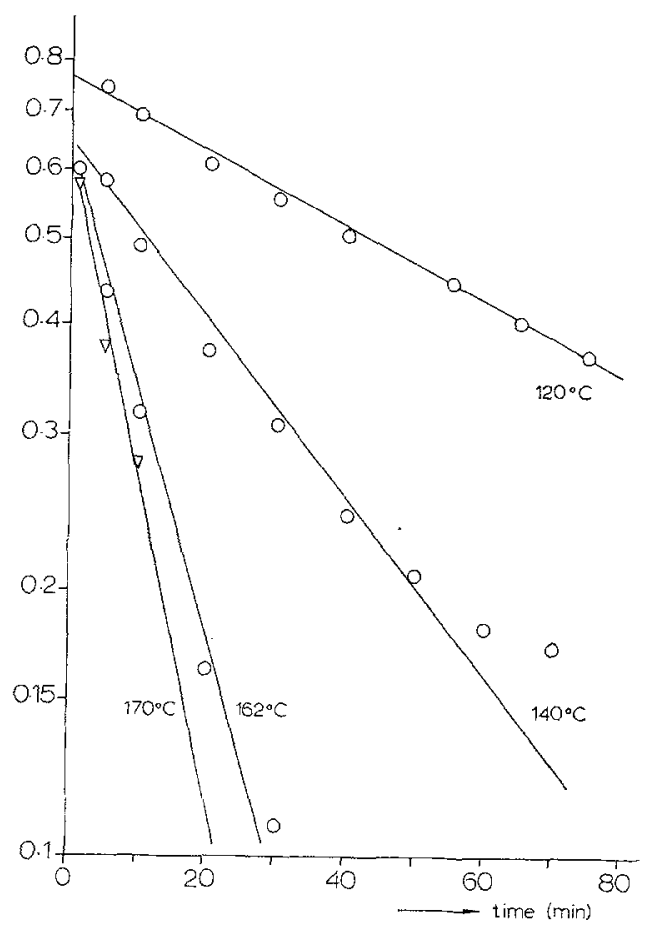

Fig. 4. Hydroformylation of octene. $c_{\mathrm{Aa}}=0.44 \mathrm{~mole} / \mathrm{lit}, \mathrm{Co}_{2}(\mathrm{CO})_{8} 0.28 \mathrm{~g}$, $p_{\mathrm{H}_{2}}=p_{\mathrm{CO}}=80 \mathrm{~atm}, \approx 400 \mathrm{~cm}^{3}$ heptan $\Theta$

tion ${ }^{14}, 5,15$. Since the intermediate reaction cannot be slower than the overall rate of the reaction, this required explanation and experimentation*.

* The rate of hydroformylation was calculated from the absorbance of olefin from the IR spectrum, and also from the G.L.C. analysis of the corresponding samples. The reaction was found to be first order with respect to the olefin, which is in agreement with literature ${ }^{16}$. Hydroformylation is a homogeneous liquid phase reaction, where the reactants $\mathrm{CO}$ and $\mathrm{H}_{2}$ diffuse from the gas phase to the liquid phase. For that reason the mass transfer phenomena were studied very carefully by stronger agitation until the conversion rate became constant ${ }^{17}$ (900 rpm in our system). In the reactions the stirring speed was therefore kept above $1000 \mathrm{rpm}$. 
The hydroformylation reaction rate constants found, as in the case of octene (Fig. 4), with different olefins at different temperatures are given in Table 1.

It is seen that the reaction rate constants increase with temperature. The plot of $\ln k$ versus $1 / T$ gives a straight line for each of the olefins

Table 1. Hydroformylation Reaction Rate Constants at: $\mathrm{CO} / \mathrm{H}_{2}=1 / 1 ; 160 \mathrm{~atm} ; 0.28 \mathrm{~g} \mathrm{Co}_{2}(\mathrm{CO})_{8} ; \mathrm{Co} /$ olefin $=1 / 20$

\begin{tabular}{lccccc}
\hline & ${ }^{\circ} \mathrm{C}$ & 118 & 120 & 142 & 162 \\
Propene & $k\left(\mathrm{~min}^{-1}\right)$ & $2.4 \times 10^{-2}$ & $2.72 \times 10^{-2}$ & $7.1 \times 10^{-2}$ & $15.2 \times 10^{-2}$ \\
& ${ }^{\circ} \mathrm{C}$ & 125 & 125 & 142 & 162 \\
Pentene & $k\left(\mathrm{~min}^{-1}\right)$ & $2.4 \times 10^{-2}$ & $3 \times 10^{-2}$ & $5.2 \times 10^{-2}$ & $13.8 \times 10^{-2}$ \\
& ${ }^{\circ} \mathrm{C}$ & 110 & 140 & 162 & 170 \\
Octene & $k\left(\mathrm{~min}^{-1}\right)$ & $9.65 \times 10^{-3}$ & $2.33 \times 10^{-2}$ & $6.40 \times 10^{-2}$ & $9.09 \times 10^{-2}$
\end{tabular}

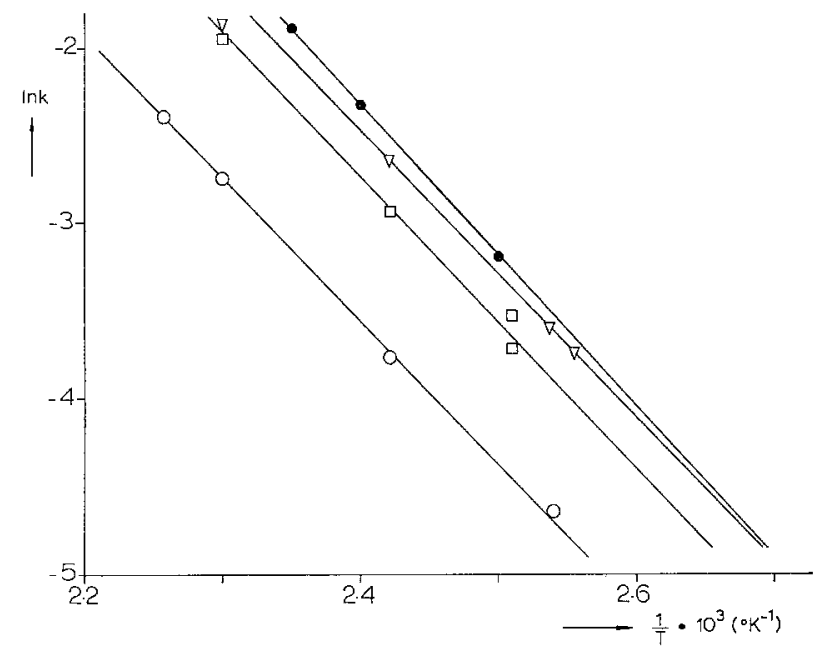

Fig. 5. Effect of temperature on the reaction rate constants of the hydroformylation of $\bigcirc$ octene, $a$ pentene and $\nabla$ propene, and on the forward reaction rate constant $\left(k_{1}=\boldsymbol{e}\right)$ of $\mathrm{Co}_{2}(\mathrm{CO})_{8}+\mathrm{H}_{2} \rightleftarrows 2 \mathrm{HCo}(\mathrm{CO})_{4}$

studied and the slopes of these lines are the same (Fig. 5), the activation energy calculated to be $16.3 \mathrm{kcal} / \mathrm{mole}$. The total activation energy of the hydroformylation is found to be independent of the kind of the straight chain terminal mono-olefins.

If the forward reaction rate constant of the formation of $\mathrm{HCo}(\mathrm{CO})_{4}$ from $\mathrm{Co}_{2}(\mathrm{CO})_{8}$ is plotted on the same graph: $\ln k$ versus $1 / T$, it is observed that the rate of formation of $\mathrm{HCo}(\mathrm{CO})_{4}$ is faster than the hydroformylation rate with any of the straight chain terminal mono-olefins used. In order to compare these data with literature, catalysts concentration 
was varied. A tenfold decrease in the catalyst concentration decreased. the reaction rate constant 10 times. Therefore using direct relationship of catalyst concentration, the reaction rate constants presented by Wender et al. ${ }^{18}$ and Kniese et al. ${ }^{19}$, extrapolated to our conditions, showed a remarkable agreement with our data.

As a conclusion we have never observed. with any olefin a hydroformylation reaction which is faster than the rate of formation of $\mathrm{HCo}(\mathrm{CO})_{4}$ from $\mathrm{Co}_{2}(\mathrm{CO})_{8}$. Therefore the earlier conclusions have to be altered in this respect ${ }^{14}$.

The parallelity of the $\ln k$ for the formation of $\mathrm{HCo}(\mathrm{CO})_{4}$ from $\mathrm{Co}_{2}(\mathrm{CO})_{8}$ to the $\ln k$ of the total hydroformylation reaction with different olefins, suggested that in the total range of temperatures the rate of formation of $\mathrm{HCo}(\mathrm{CO})_{4}$ is greater than the hydroformylation rate. Therefore it can be an intermediate reaction in the hydroformylation. The activation energy of this intermediate reaction and that of hydroformylation are about the same. The total energy barrier to hydroformylation is equal to the barrier which must be overcome in the formation of $\mathrm{HCo}(\mathrm{CO})_{4}$ from $\mathrm{Co}_{2}(\mathrm{CO})_{8}$, which is the rate determining step.

Once active catalyst $\mathrm{HCo}(\mathrm{CO})_{4}$ is prepared, the hydroformylation reaction proceeds at stoichiometric conditions: $1 \mathrm{~atm}$ and $25^{\circ} \mathrm{C}$; the reaction is complete in a few minutes even at $0^{\circ} \mathrm{C}$ (Karapink $\left.{ }^{20}\right)$. The reaction mechanism, studied thoroughly at stoichiometric conditions, showed that the hydrogenolysis of acylcobaltcarbonyl is performed by $\mathrm{HCo}(\mathrm{CO})_{4}$. More evidence about the intermediates and their change in concentration with time at $10^{\circ} \mathrm{C}$ has been presented by Gankin et al. ${ }^{7,8}$. The reversibility of all the steps in the hydroformylation except the hydrogenolysis of acylcobaltcarbonyls to aldehyde, has been proved. exclusively by Orchin et al. ${ }^{21}$. Our results support the fact that the formation of intermediates and the reactions leading to aldehyde are very fast. The reaction rates are not affected by the increase in temperature, therefore they have very low activation energies. But the temperature effect on the rate of formation of $\mathrm{HCo}(\mathrm{CO})_{4}$ is very much pronounced as it is obvious from Fig. 5. The mechanism of the reaction can be given as follows:

$$
\begin{aligned}
& \mathrm{Co}_{2}(\mathrm{CO})_{8}+\mathrm{H}_{2} \rightleftarrows 2 \mathrm{HCo}(\mathrm{CO})_{4} \\
& \mathrm{HCo}(\mathrm{CO})_{4}+\text { olefin } \rightleftarrows \mathrm{RC}=\mathrm{C} \rightleftarrows \mathrm{RCo}(\mathrm{CO})_{4} \\
& \mathrm{HCo}(\mathrm{CO})_{4} \\
& \mathrm{RCo}(\mathrm{CO})_{4} \rightleftarrows \mathrm{RCOCo}(\mathrm{CO})_{3} \\
& \mathrm{RCOCo}(\mathrm{CO})_{3}+\mathrm{CO} \longrightarrow \mathrm{RCOCo}(\mathrm{CO})_{4} \\
& \mathrm{RCOCo}(\mathrm{CO})_{4}+\mathrm{HCo}(\mathrm{CO})_{4} \rightarrow \mathrm{RC}=\mathrm{O}+\mathrm{Co}_{2}(\mathrm{CO})_{8} \\
& \mathrm{H}
\end{aligned}
$$


This mechanism is in agreement with our observations. The decrease in the intensity of the acyl complex, showed the same type of decrease in $\Delta$. The intensity of the absorption of the olefins decreased. The evidence for $\pi$ and the alkyl complex is still lacking. Further studies in the mechanism reveal that the initial rate of formation of intermediates via the reaction between olefin and $\mathrm{HCo}(\mathrm{CO})_{4}$ was $0.766 \mathrm{mmole} / \mathrm{min}$. The achievement of steady-state condition in the intermediate complexes, shown in Fig. 3 as $\Delta$, implied that the steps of reactions leading to aldehyde were faster than the initial step of the formation of the $\pi$ complex. During the reaction more than $30 \%$ of the initial cobalt charged was present in the form of $\mathrm{HCo}(\mathrm{CO})_{4}$. If the hydrogenation step of the acyl complex was slower than the initial step of reaction between olefin and $\mathrm{HCo}(\mathrm{CO})_{4}$, one would observe a continuous increase in concentration of the intermediates and a continuous decrease in concentration of $\mathrm{HCo}(\mathrm{CO})_{4}$ during the progress of the reaction. From our observations this is not the case. Therefore the next slowest step besides the formation of $\mathrm{HCo}(\mathrm{CO})_{4}$, is its reaction with olefin to form the intermediate complexes. The rate constant of the hydroformylation reaction, starting with olefin and $\mathrm{HCo}(\mathrm{CO})_{4}$, after eliminating the formation of $\mathrm{HCo}(\mathrm{CO})_{4}$, shows that, with the increase in the chain of the terminal mono-olefin, there is a decrease in the rate of hydroformylation. (Fig. 6). The ln rate constant versus the carbon number of the olefin, clearly indicates the above fact.

By assuming steady-state condition for the intermediates the reaction mechanism presented. would lead to a rate which is proportional to the concentration of olefin and $\mathrm{HCO}(\mathrm{CO})_{4}$. Therefore the formation of hydrocobalttetracarbonyl going via route II :

$$
\mathrm{H}_{2}+\mathrm{Co}_{2}(\mathrm{CO})_{6} \rightarrow \mathrm{H}_{2} \mathrm{Co}_{2}(\mathrm{CO})_{6} \rightleftarrows 2 \mathrm{HCo}(\mathrm{CO})_{3}
$$

presented in ${ }^{13}$, would lead to the kinetic measurements by Natta $^{16}$.

The solvent effects on the reaction can be explained by the solubilities of the components of the reaction in that solvent. There is still no clear explanation for the product distribution of the oxo reaction with $\mathrm{CO}_{2}(\mathrm{CO})_{8}$. The increase of $\mathrm{CO}$ pressure increases the normal product, which implies the presence of two catalytically active species, as suggested by Piacenti ${ }^{22}$. But the isomerization of the olefin or isomerization of the acyl complex, claimed by Orchin ${ }^{23}$, cannot be disregarded. Whether the initial addition of the catalytically active species (Markovnikov or anti-Markovnikov) supported by Gankin et al. ${ }^{9}$, or the isomerization of the intermediates determines the final product distribution, is still an unsolved problem. We have observed the effects of temperature and $\mathrm{CO}$ pressure on the product distribution, but we never detected any clue in our experiments with the IR cell which may lead to a satis- 
factory answer. The D.P.T.C. (Differential Pressure and Temperature Cell) ${ }^{13}$ measurement may support the presence of two catalytically active species as suggested by Piacenti ${ }^{22}$ and Pino et al. ${ }^{24}$. These species may differ in their hydridic and protonic characters, the effect of which leads to a change of product distribution of normal to iso aldehydes. This, however, is speculative and by no means conclusive.

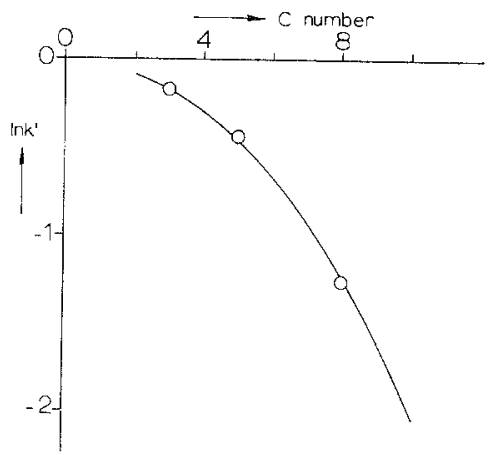

Fig. 6. Effect of the carbon number of terminal mono-olefin on the hydroformylation rate constant $k^{\prime} . \quad \ln k^{\prime}=\ln$ (total hydroformylation rate)In [rate constant for the forward reaction of $\mathrm{Co}_{2}(\mathrm{CO})_{8}+\mathrm{H}_{2} \rightleftarrows 2 \mathrm{HCo}(\mathrm{CO})_{4}$ ]

\section{Experimental}

Experiments were performed in the same apparatus as given in previous papers ${ }^{12,13}$.

The conversion of the olefin was determined by the absorbance of the double bond at $\approx 1825 \mathrm{~cm}^{-1}$. In addition to this, G.L.C. analyses of the samples taken at various reaction times were made.

The optimum separation is achieved with a stainless steel column ( $4 \mathrm{~mm} \times 4 \mathrm{~m}$ or $12 \mathrm{~m}$ ), packed with a Chromosorb W-Carbowax $20 \mathrm{M}$ (80-20 wt \% mixture).

The gas chromatograph used is the Research Chromatograph 5720 Hewlett Packard. The peak areas are directly integrated by Infotronics Digital Read out System, Model CRS-104. A flame ionization detector is used. $\mathrm{N}_{2}$ is the carrier gas. The program is such that for 16 minutes it remains at $40^{\circ} \mathrm{C}$, then temperature increases to $175^{\circ} \mathrm{C}$, at a rate of $10^{\circ} \mathrm{C} / \mathrm{min}$ and remains at this upper limit for 10 minutes.

Dodecane acted as an internal standard.

\section{Acknowledgement}

The authors are indebted to Messrs. J. M. Alberigs and A. H. Pleiter for their help in construction of the apparatus and in the experiments 
and to Mr. G.J. H. Altena for his help in G. L.C. analysis. Special thanks are due to Mrs. C. M. Meulstee-van Horn for her critical and highly efficient typing and Mr. R. H. Arends for his skilful drawings.

The first author expresses his thanks to the Ministry of Education of Turkey for providing the grant during the $\mathrm{Ph} . \mathrm{D}$. studies in the Netherlands.

\section{Referenees}

1 O. Roelen (Ruhr Chemie A.G., Process for Preparing Valuable Oxo Products). (a) Ger. Pat. Appl. R. 10. 3. 362, R 402, Sept. 19, 1938. (b) Ruhr Chemie, Ger. Pat. 849,548 (1938). (c) O. Roelen, Angew. Chem. A 60, 213 (1948).

2 D. S. Breslow and R. F. Heck, Chem, and Ind, 1960, 467.

3 R. F. Heck and D. S. Breslow, J. Amer. Chem. Soc. 83, 4023 (1961).

4 L. Kirch and M. Orchin, J. Amer. Chem. Soc. 81, 4200 (1959).

5 E. G. Hancock, Propylene and its Industrial Derivates, Ch. 9, p. 333. Ernest Benn Ltd., 1973.

6 Kirk-Othmer, Encyclopedia of Chemical Technology, Vol. 14, 373 (1964). Wiley.

7 V. Yu Gankin, V. Congr. on Catal., Vol. 1, 25-421 (1972).

${ }^{8}$ V. Yu Gankin, V. L. Klimenko, V.A. Ribakov, and V.A. Divinin, Symp. on Hydrof., Veszprém 1972, p. 32.

9 V. Yu Gankin, V.A. Divinin, V. P. Novikov, V. A. Ribakov, and S.K. Skop, Kinetika i Kataliz 14, 1149 (1973).

$10 R$. Whyman, J. Organometall. Chem. 66, c 23-c 25 (1974).

11 L. Markó, G. Bor, G. Almásy, and P. Szabó, Brennstoff-Chem. 44, (6) 184 (1963).

${ }^{12}$ E. Oltay, J.M.L. Penninger, N.H. Alemdaroğlu, and J.M. Alberigs, Anal. Chem. 45, 802 (1973).

${ }^{13}$ N.H. Alemdaroğlu, J.M.L. Penninger, and E. Oltay, Mechanism of Hydroformylation, Part II. Mh. Chem. 107, 1043 (1976).

$14 \mathrm{~J}$. Falbe, Carbon Monoxide in Organic Synthesis, p. 16. Berlin-Heidelberg-New York: Springer. 1970.

15 R. Iwanaga, Bull. Chem. Soc. Jap. 35, 778 (1962).

16 G. Natta, R. Ercoli, and S. Castellano, Chim. Ind. [Milano] 37, 6 (1955).

17 B. Silberstein, Ph.D. Dissertation, Yale Univ. 1969, 69-8435.

18 I. Wender, S. Metlin, S. Ergun, H.W. Sternberg, and H. Greenfield, J. Amer. Chem. Soc. 78, 5401 (1956).

19 W. Kniese, H. J. Nienburg, and R. Fisher, J. Organometall. Chem. 17, $133(1969)$.

${ }_{20} G$. L. Karapinka and M. Orchin, J. Org. Chem. 26, 4187 (1961).

21 W. Rupilius and M. Orchin, J. Org. Chem. 37, 936 (1972).

${ }^{22}$ J. F. Piacenti, P. Pino, R. Lazzaroni, and M. Biachi, J. Chem. Soc. C 1966, 488. 
${ }^{23} M$. Orchin and W. Rupilius, Catal. Rev 6 (1), 85-131 (1972).

${ }_{24}$ D. A. von Bézard, G. Consiglio, and P. Pino, Chimia 28, 610 (1974).

${ }_{25}$ W. Rigby, R. Whyman, and K. Wilding, J. Phys. Eng. Sci., Instrum. 3, $1570(1970)$.

Correspondence and reprints:

Prof. Dr. E. Oltay

Institut für chemische Technologie organischer Stoffe

Johannes Kepler-Hochschule

A-4045 Linz-Auhof

Austria 